\title{
Physiological effects of the combined stresses of freezing-thawing, acid precipitation and deicing salt on alfalfa seedlings
}

\author{
Guozhang Bao*, Wenyi Tang, Qirui An, Yaoxin Liu, Jiaqi Tian, Nan Zhao and Saning Zhu
}

\begin{abstract}
Background: Frequent freeze-thaw phenomena, together with widely used deicing salt and intense acid precipitation, often occur in northeastern China, causing damage to various aspects of plants, such as the permeability of biological membranes, osmotic adjustment, and photosystems. Aiming to explore the resistance of alfalfa to freezing-thawing (F), acid precipitation (A) and deicing salt (D), this study used Medicago sativa cV. Dongmu-70 as the experimental material, and the contents of malondialdehyde (MDA), soluble protein, soluble sugars, proline and chlorophyll were evaluated.

Results: As the temperature decreased, the MDA content in the seedlings of the group under combined stress (A-D-F) increased and was significantly higher than that of group F (by 69.48 136.40\%). Compared with those in the control (CK) group, osmotic substances such as soluble sugars and proline in the treatment groups were higher, while the soluble protein content was lower. The chlorophyll contents in the seedlings of the treatment groups were lower than those of the CK group; however, the chlorophyll content displayed a non-significant change during the free-thaw cycle.

Conclusion: Injury to the permeability of the biological membranes and photosystems of alfalfa results from stress. Moreover, alfalfa maintains osmotic balance by adaptively increasing the potential of osmotic substances such as soluble sugars and proline. Furthermore, the influence of stress from freezing-thawing and deicing salt is highly substantial, but the combined stresses of acid precipitation with the two factors mentioned above had little effect on the plants.
\end{abstract}

Keywords: Freeze-thaw, Acid precipitation, Deicing salt, Combined stress, Alfalfa

\section{Background}

Freezing-thawing refers to the physical geologic phenomenon of the soil layer freezing and melting during late winter and early spring, which occurs in northeastern China [1], and can harm plants [2]. It has been reported that grass-type plants resist low-temperature

\footnotetext{
* Correspondence: baogz@jlu.edu.cn

Laboratory of Groundwater Resources and Environment of the Ministry of Education, College of New Energy and Environment, Jilin University,

Changchun 130012, China
}

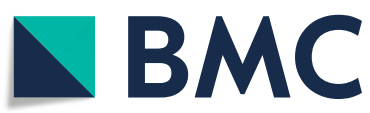

(c) The Author(s). 2020 Open Access This article is licensed under a Creative Commons Attribution 4.0 International License, which permits use, sharing, adaptation, distribution and reproduction in any medium or format, as long as you give appropriate credit to the original author(s) and the source, provide a link to the Creative Commons licence, and indicate if changes were made. The images or other third party material in this article are included in the article's Creative Commons licence, unless indicated otherwise in a credit line to the material. If material is not included in the article's Creative Commons licence and your intended use is not permitted by statutory regulation or exceeds the permitted use, you will need to obtain permission directly from the copyright holder. To view a copy of this licence, visit http://creativecommons.org/licenses/by/4.0/ The Creative Commons Public Domain Dedication waiver (http://creativecommons.org/publicdomain/zero/1.0/) applies to the data made available in this article, unless otherwise stated in a credit line to the data.

damage by regulating their proline content [3]. Additionally, considering the frequent and heavy snowfall in winter, deicing salt is widely used because of its low cost, regardless of the severe damage it causes to roadside plants in the form of either runoff or splashing $[4,5]$. In addition, the extensive use of coal and oil, as well as the production of sulfur dioxide from coal burning during the winter in northern China, can cause acid precipitation [6]. Moreover, after North America and Europe, 
China is the third largest area subjected to acid precipitation in the world [7].

Alfalfa is characterized by its adaptability to adversities such as cold, heat, and drought and is widely cultivated in high-latitude areas in China [8], where acid deposition and deicing salt accompanied by freezing-thawing often occur together. A number of previous studies have investigated the resistance of alfalfa under individual factors $[9,10]$; however, in the actual environment, plants are often affected by multiple factors. Hence, studying the physiological responses of alfalfa to combined stresses is urgently needed. In this experiment, Medicago sativa cv. Dongmu-70 was used as the experimental material to study the physiological responses to combined stresses. Malondialdehyde (MDA) is an end-product of membrane lipid peroxidation, and the MDA content can indicate the extent of cell membrane damage [11]. Soluble protein, soluble sugars and proline are osmotic adjustment substances that can promote cellular bound water content [12]. In addition, chlorophyll content can reflect the photosynthetic intensity and the rate of material synthesis, indicating the level of damage [13]. The above indexes were measured to explore the resistance of alfalfa to acid precipitation, deicing salt and freezethaw cycles to provide a theoretical basis for improving the cultivation technology to alleviate damage to plants.

\section{Results}

\section{Changes in MDA content}

Figure 1 shows that the MDA content in the seedlings of groups under combined stresses (A-F, D-F and A-D-F) was higher than that of the group under freeze-thaw (F) stress alone by $7.87 \sim 62.60 \%, 63.40 \sim 120.96 \%$ and 69.48 $\sim 136.40 \%$, respectively (see Additional file 1). This indicates that combined stresses cause more intense stress conditions, resulting in the accumulation of MDA in the alfalfa plants. During the thawing period $(8 \sim 14 \mathrm{~h})$, the MDA content measured in the seedlings of groups under either combined stresses or freeze-thaw stress alone decreased. When the temperature rose to $10^{\circ} \mathrm{C}$ (14 h), the MDA content in the seedlings of groups A-F, D-F and A-D-F decreased by 57.58, 42.10 and $40.20 \%$, respectively (see Additional file 1). It can also be observed from Fig. 1 that under freeze-thaw stress, the MDA content in the seedlings of group A-D-F was significantly higher than that of group A-F $(P<0.05)$, while it showed no significant difference compared with that of group D-F $(P>0.05)$. The above results indicated that the combined stresses had a more significant effect on the MDA content in seedlings than did the freeze-thaw stress alone, and deicing salt stress had a greater impact on the MDA content than did the acid precipitation and freeze-thaw stress.

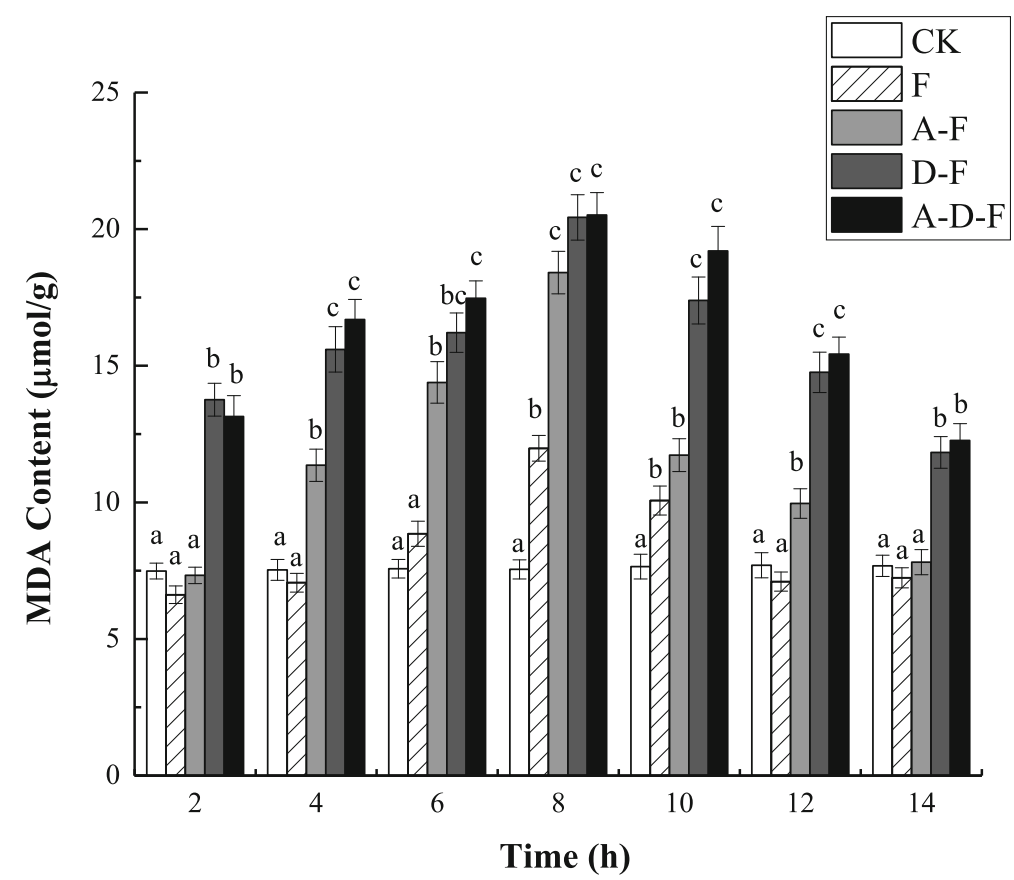

Fig. 1 Combined effects of freezing-thawing, deicing salt and acid precipitation on the MDA content in alfalfa seedlings (means \pm SEs, $n=3$ ). The numbers from $2 \sim 14 \mathrm{~h}$ represent different temperatures corresponding to $10,5,0,-5,0,5$, and $10^{\circ} \mathrm{C}$. CK represents the control group. The letters $A, D$ and $F$ represent the acid precipitation treatment, deicing salt treatment and freeze-thaw treatment, respectively. The different letters indicate significant differences among the various treatments $(P<0.05)$ 


\section{Changes in soluble protein content}

According to Fig. 2, the soluble protein content in the seedlings of the combined stress groups tended to increase initially but then decrease throughout the whole freeze-thaw cycle, while that of the freeze-thaw stress alone group showed a dynamic decrease. When the temperature decreased to $0{ }^{\circ} \mathrm{C}(6 \mathrm{~h})$, the soluble protein content in the seedlings of groups under the combined stresses peaked. At the thawing stage $(8 \sim 14 \mathrm{~h})$, the soluble protein content in the seedlings of groups under freeze-thaw stress was significantly lower than that of the control $(\mathrm{CK})$ group $(P<0.05)$ (see Additional file 2$)$, which may be attributed to the addition of freeze-thaw stress. However, the content of soluble protein in the seedlings of groups under compound stresses showed no significant difference compared with that of the group under freeze-thaw stress alone, indicating that either acid precipitation stress or deicing salt stress had a lower impact on the soluble protein content. Moreover, during this period, a higher soluble protein content was detected in the freeze-thaw group than in the combined stress groups, indicating that the combined stresses caused more damage to the plants than did the individual stresses.

\section{Changes in soluble sugar content}

Figure 3 shows that the soluble sugar content of each test group was significantly higher than that of the CK group during the freeze-thaw cycle. When the temperature decreased, the soluble sugar content in the seedlings of all groups except the CK group increased and peaked at $5^{\circ} \mathrm{C}(8 \mathrm{~h})$. These results demonstrated that in the lowtemperature environment, the soluble sugar content in the plants increased significantly, and the plants protected themselves by accumulating a large amount of soluble sugars. The highest soluble sugar content was measured in plants subjected to the combined stresses of freezingthawing, deicing salt and acid precipitation. During the thawing period $(8 \sim 14 \mathrm{~h})$, the soluble sugar content in the seedlings of all the groups except the CK tended to decrease as the temperature increased. Notably, when the temperature rose from $-5^{\circ} \mathrm{C}(8 \mathrm{~h})$ to $0^{\circ} \mathrm{C}(10 \mathrm{~h})$, the soluble sugar content in the seedlings of group $\mathrm{F}$ was significantly lower than that of group A-D-F (by $17.13 \%(8 \mathrm{~h})$ and $14.79 \%(10 \mathrm{~h})$ ) (see Additional file 3$)(P<0.05)$, but the soluble sugar content in the seedlings of groups A-F and D-F did not differ significantly from that of group $\mathrm{F}$ $(P>0.05)$. These findings indicated that the conditions resulting from the combination of the three stress factors caused the maximum accumulation of soluble sugars in the plants.

\section{Changes in proline content}

As shown in Fig. 4, the proline content in the seedlings of the test groups was higher than that of the CK group throughout the whole freeze-thaw period, indicating that stresses resulting from acid precipitation and deicing salt caused an increase in proline content in the plants.

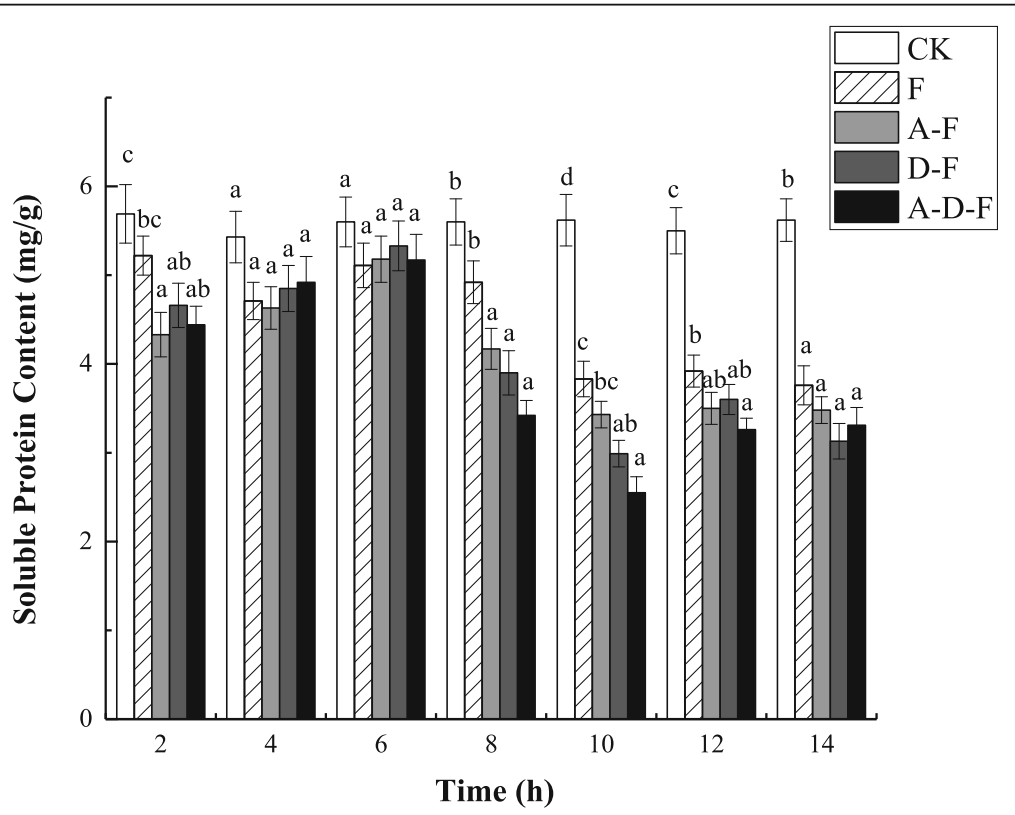

Fig. 2 Combined effects of freezing-thawing, deicing salt and acid precipitation on the soluble protein content in alfalfa seedlings (means \pm SEs, $n=3$ ). The numbers from $2 \sim 14 \mathrm{~h}$ represent different temperatures corresponding to $10,5,0,-5,0,5$, and $10^{\circ} \mathrm{C}$. CK represents the control group. The letters A, D and F represent the acid precipitation treatment, deicing salt treatment and freeze-thaw treatment, respectively. The different letters indicate significant differences among the various treatments $(P<0.05)$ 


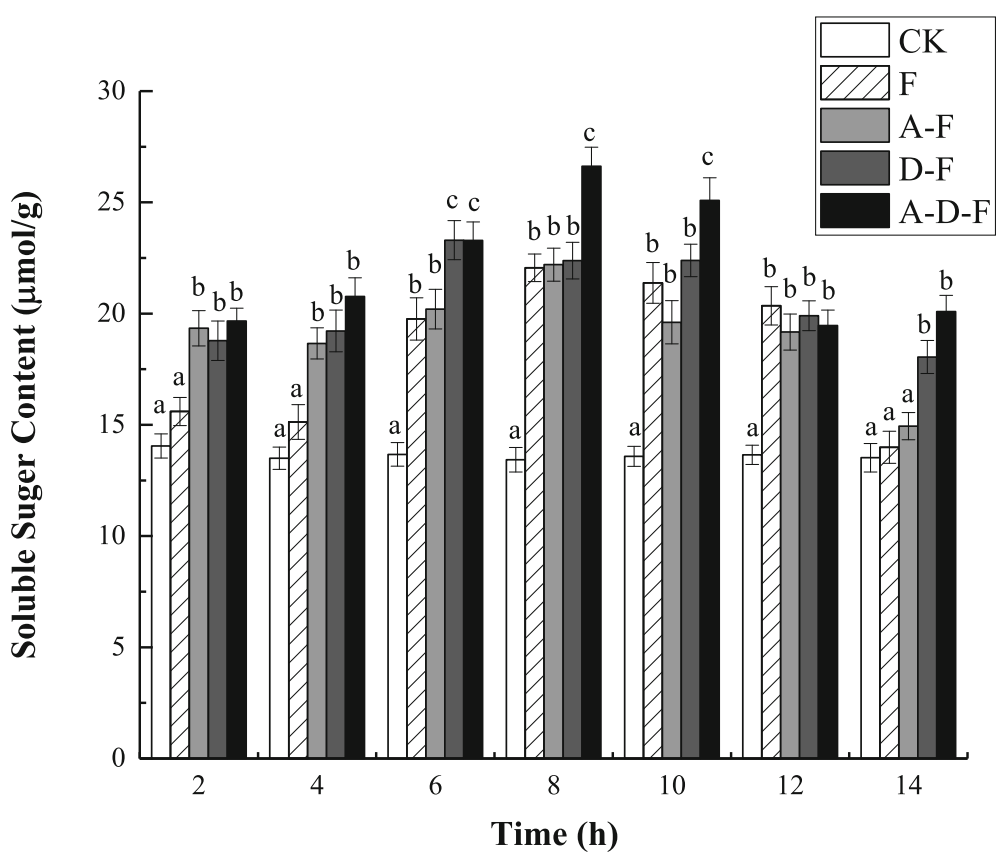

Fig. 3 Combined effects of freezing-thawing, deicing salt and acid precipitation on the soluble sugar content in alfalfa seedlings (means \pm SEs, $n=3)$. The numbers from $2 \sim 14 \mathrm{~h}$ represent different temperatures corresponding to $10,5,0,-5,0,5$, and $10^{\circ} \mathrm{C}$. CK represents the control group. The letters A, D and F represent the acid precipitation treatment, deicing salt treatment and freeze-thaw treatment, respectively. The different letters indicate significant differences among the various treatments $(P<0.05)$

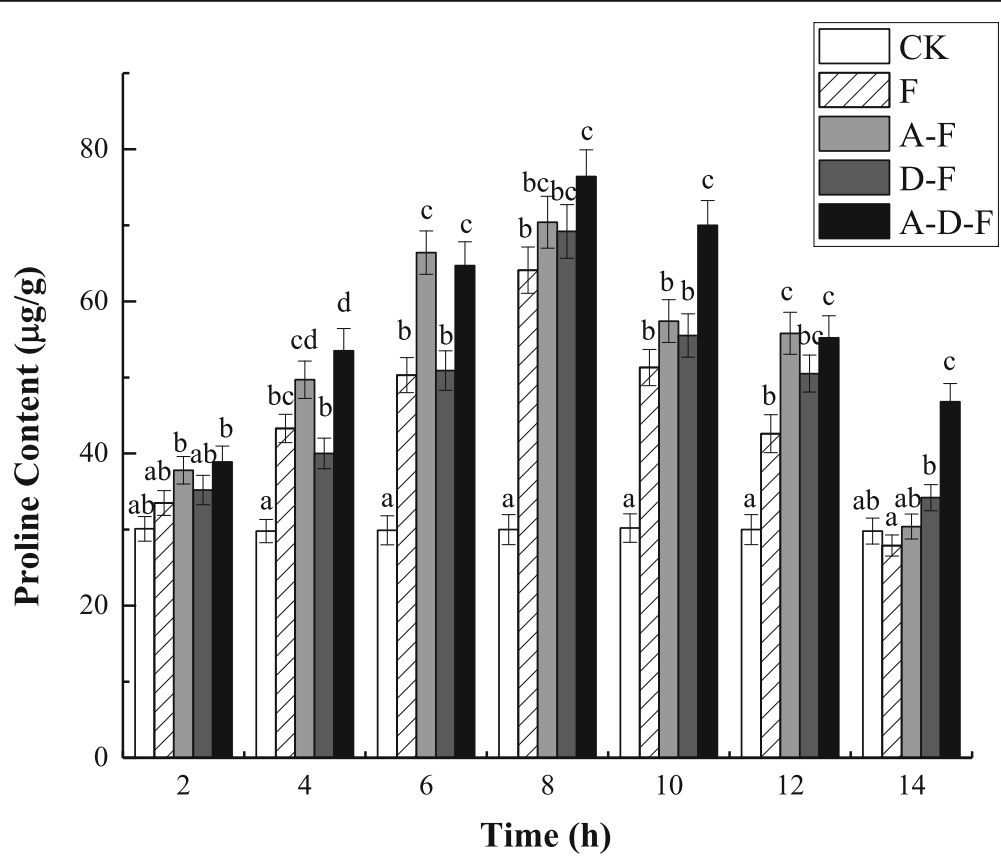

Fig. 4 Combined effects of freezing-thawing, deicing salt and acid precipitation on the proline content in alfalfa seedlings (means \pm SEs, $n=3$ ). The numbers from $2 \sim 14 \mathrm{~h}$ represent different temperatures corresponding to $10,5,0,-5,0,5$, and $10^{\circ} \mathrm{C}$. CK represents the control group. The letters $\mathrm{A}, \mathrm{D}$ and $\mathrm{F}$ represent the acid precipitation treatment, deicing salt treatment and freeze-thaw treatment, respectively. The different letters indicate significant differences among the various treatments $(P<0.05)$ 
During the freezing period, the proline content in the seedlings of groups F, A-F, D-F and A-D-F increased and peaked at $-5^{\circ} \mathrm{C}(8 \mathrm{~h})$; the contents were 91.34, 86.24, 96.59 and $96.40 \%$ higher than those measured at $10{ }^{\circ} \mathrm{C}(2 \mathrm{~h})$, respectively (see Additional file 4). During the thawing period $(8 \sim 14 \mathrm{~h})$, the proline content of groups F, A-F, D-F and A-D-F at $-5^{\circ} \mathrm{C}(8 \mathrm{~h})$ decreased by $19.97,18.46,19.80$ and $8.38 \%$, respectively, compared with those measured at $0^{\circ} \mathrm{C}(10 \mathrm{~h})$ (see Additional file 4). Figure 4 also showed that the proline content was significantly higher in group A-D-F than in the group subjected to only freezing-thawing $(P<0.05)$. In addition, except for that in the CK group, the proline content in the seedlings of the groups under acid precipitation stress was significantly higher than that of the groups not under acid rain stress $(P<0.05)$, which indicated that freeze-thaw stress accompanied by acid precipitation stress resulted in more proline produced in plants to protect themselves.

\section{Changes in chlorophyll content}

During the freeze-thaw period, the chlorophyll content in the seedlings of each experimental group exhibited an initial decrease followed by an increase (Fig. 5). At the freezing stage, the chlorophyll content in groups F, A-F, D-F and A$\mathrm{D}-\mathrm{F}$ tended to decrease and reached the minimum value at $-5^{\circ} \mathrm{C}(8 \mathrm{~h})$, which were $22.38,12.73,11.11$ and $17.79 \%$ lower than those measured at $10^{\circ} \mathrm{C}(2 \mathrm{~h})$, respectively (see Additional file 5). During the thawing period $(8 \sim 14 \mathrm{~h})$, compared with the chlorophyll content measured at $-5^{\circ} \mathrm{C}$ $(8 \mathrm{~h})$, the content measured at $10^{\circ} \mathrm{C}(14 \mathrm{~h})$ in the seedlings of groups F, A-F, D-F and A-D-F significantly increased by 42.32, 25.60, 25.77 and $20.65 \%$, respectively $(P<0.05)$ (see Additional file 5). However, there was no significant difference in chlorophyll content among the experimental groups throughout the whole freeze-thaw period $(P>0.05)$.

\section{Correlation analysis between indexes}

Table 1 shows that under freeze-thaw conditions, MDA and proline were significantly positively correlated $(P<$ 0.01 ), each of which was positively correlated with soluble sugars $(P<0.05)$. Chlorophyll was negatively correlated with MDA, proline and soluble sugars. However, there was no significant correlation between protein and the other indicators. The correlations between the indexes of the freeze-thaw + acid precipitation + deicing salt group were similar to those of the freeze-thaw group, but all correlations were highly significant in the former group $(P<$ $0.01)$. These findings indicated that both proline and the soluble sugar content increased with the accumulation of MDA in plants under external stress, while the chlorophyll content decreased.

\section{Discussion}

\section{Effects of combined stresses on the membrane system}

MDA is one of the main products of membrane peroxidation in plants under adverse conditions and can strongly

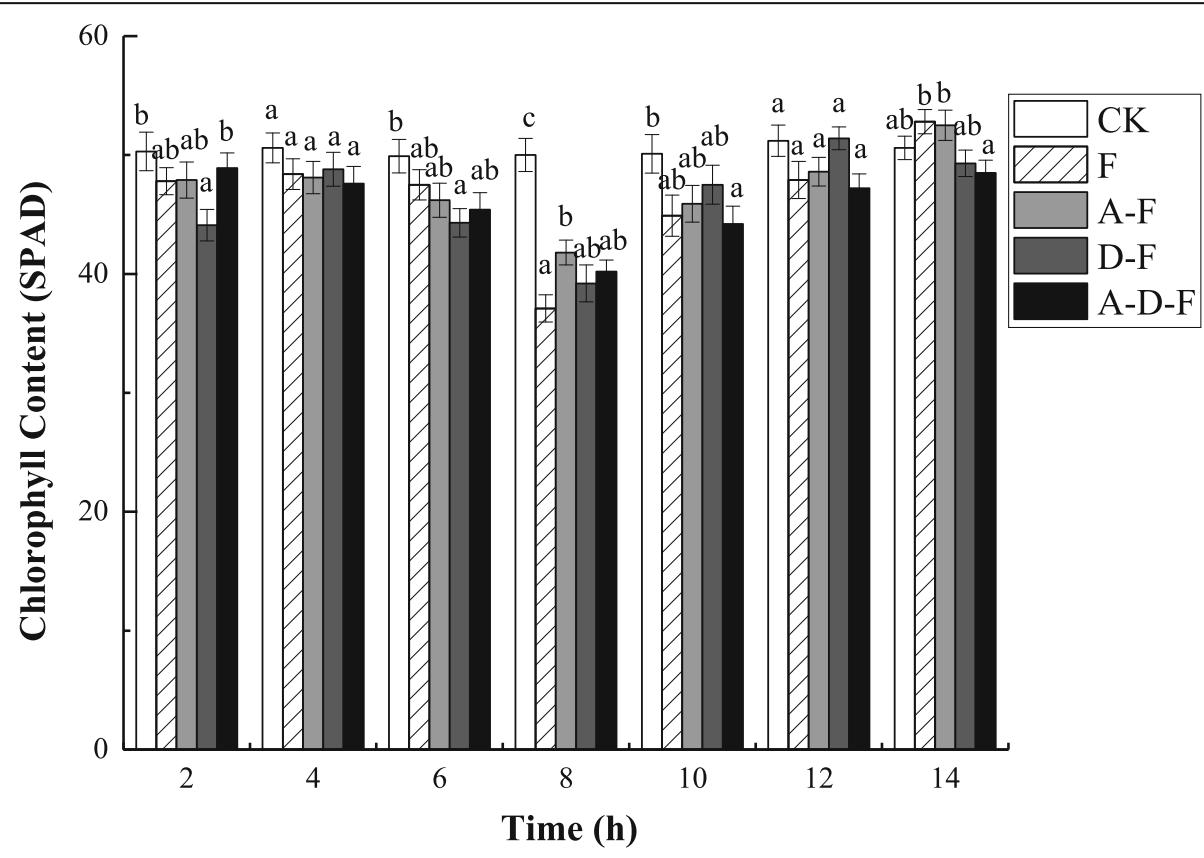

Fig. 5 Combined effects of freezing-thawing, deicing salt and acid precipitation on the chlorophyll content in alfalfa seedlings (means \pm SEs, $n=$ 3). The numbers from $2 \sim 14 \mathrm{~h}$ represent different temperatures corresponding to $10,5,0,-5,0,5$, and $10^{\circ} \mathrm{C}$. CK represents the control group. The letters $A, D$ and $F$ represent the acid precipitation treatment, deicing salt treatment and freeze-thaw treatment, respectively. The different letters indicate significant differences among the various treatments $(P<0.05)$ 
Table 1 Pearson correlation analysis under freeze-thaw (F) and combined (A-D-F) stresses

\begin{tabular}{|c|c|c|c|c|c|c|}
\hline & & MDA & soluble protein & chlorophyll & proline & soluble sugars \\
\hline \multirow[t]{5}{*}{ Freeze-Thaw Group } & MDA & 1.000 & & & & \\
\hline & soluble protein & 0.090 & 1.000 & & & \\
\hline & chlorophyll & $-0.867^{b}$ & -0.348 & 1.000 & & \\
\hline & proline & $0.887^{\mathrm{a}}$ & 0.270 & $-0.904^{\mathrm{a}}$ & 1.000 & \\
\hline & soluble sugars & $0.781^{b}$ & 0.016 & $-0.761^{b}$ & $0.855^{\mathrm{b}}$ & 1.000 \\
\hline \multirow{5}{*}{$\begin{array}{l}\text { Freeze-Thaw +Acid } \\
\text { Precipitation +deicing } \\
\text { salt Group }\end{array}$} & MDA & 1.000 & & & & \\
\hline & soluble protein & -0.153 & 1.000 & & & \\
\hline & chlorophyll & $-0.904^{\mathrm{a}}$ & 0.296 & 1.000 & & \\
\hline & proline & $0.946^{\mathrm{a}}$ & -0.291 & $-0.936^{\mathrm{a}}$ & 1.000 & \\
\hline & soluble sugars & $0.895^{\mathrm{a}}$ & -0.261 & $-0.947^{\mathrm{a}}$ & $0.921^{a}$ & 1.000 \\
\hline
\end{tabular}

indicates a significant correlation at the 0.01 level

${ }^{b}$ indicates a significant correlation at the 0.05 level

react with various components in the cell, causing crosslinking polymerization of macromolecules such as proteins and nucleic acids [14], leading to membrane structure damage and impaired physiological function $[15,16]$. It has been pointed out that the degree of membrane damage caused by the complex stress environment caused by freezing-thawing, acid precipitation and deicing salt could be characterized by changes in MDA content [17]. In this experiment, the damage to the cell membrane caused by three stress factors resulted in the most obvious increase in MDA content at $-5^{\circ} \mathrm{C}$, indicating that the combined stresses caused more severe membrane lipid peroxidation injury to the seedlings than did the individual stresses, which is consistent with published results about the effects of low-temperature stress on plant physiological indexes $[18,19]$. Similar to the results of research on M. sativa L. under salt stress [20], in this experiment, it was pointed out that salt stress aggravated the damage to the membrane and led to an increase in MDA content.

\section{Effects of combined stresses on osmotic adjustment substances}

Protein is the material basis of life, the most abundant organic macromolecule in plant cells, the basic unit of organic matter that constitutes cells, and the main component of enzymes, which participate in chemical reactions in cells [21]. It can be seen that the soluble protein contents in the seedlings of groups under stress were lower than those in the CK group under freeze-thaw stress, which could be explained by the reduction in the activity of either protein synthetases or other enzymes in plants under adverse conditions, resulting in a decrease in soluble protein content. This result is similar to that presented by Mao and $\mathrm{Xu}$, who reported that salt treatment leads to a decrease in protein content in plant seedlings [11]. The soluble protein content in seedlings increased with decreasing temperature in this experiment, which was attributed to the enhanced expression of related genes, which could effectively stimulate the accumulation of protective substances, reduce cell metabolism and facilitate resistance to low temperature [22]. The reason why the soluble protein decreased during the period in which the temperature decreased to $-5^{\circ} \mathrm{C}$ and increased to $10^{\circ} \mathrm{C}$ might be that the protein was consumed when the plants adapted to adverse conditions and maintained growth, similar to the results of Fleck et al., who investigated the protein content in winter wheat leaves and their freezing resistance [23].

Free proline is an important osmotic regulator in plants. It has been reported that under stress conditions, the proline mass ratio in plant cells greatly increases, which reduces the cell osmotic potential and helps cells absorb water, thus preventing protoplasm and protein molecules from dehydrating [24]. Hence, a change in the proline content can be used as an indicator of the cold resistance of plants [3]. The results of this experiment showed that the proline content of all groups significantly increased in the low-temperature environment. This is consistent with the research results of Hare et al., who analysed the cumulative effects of osmotic pressure under stress conditions and suggested that proline improved the stress resistance to low temperature [25]. Li et al. not only found that the accumulation of osmotic adjustment substances such as proline can decrease the cellular water potential and maintain osmotic balance but also demonstrated that, to some extent, the more anticold capability plants exhibit, the more significant the change in proline content [26]. Acid precipitation can cause acute injury to leaves and can restrict growth. As such, in this experiment, the proline content was more strongly influenced in the A-D-F group than in the other groups.

Soluble sugars play an important role in the growth cycle of plants. It has been pointed out that under salt 
stress, plants can accumulate a large number of osmotic regulators, such as soluble sugars and other inorganic salt ions [27], which can reduce the osmotic potential in cells, enhance water absorption and water holding capacity, and maintain cell growth, thus enhancing the ability to resist stress $[28,29]$. As a result, an upward trend of soluble sugar content in seedlings was detected in this study, indicating that plants can protect themselves under adverse conditions by accumulating soluble sugars [30]. This may be due to the increasing cell fluid concentration in plants subjected to low-temperature stress, lowering the freezing point and reducing the excessive dehydration of cells; thus, the protoplasm colloid was protected from cold-induced coagulation, enhancing adaptability to low-temperature stress [31]. It was also found that the soluble sugar content of the A-D-F group was much higher than that of the control group, owing to more soluble sugars activating the osmotic pressure regulatory mechanism in plants to resist the combination of stresses [32].

\section{Effects of combined stresses on chlorophyll content}

The pigment in the leaves is designed to absorb light energy and provide energy for plant growth; thus, the responses of chlorophyll content to adverse environments can indicate the ability of photosynthesis [25, 33]. Consistent with the results of this experiment by which the chlorophyll content in the seedlings of group F was reduced, Xin and Browse pointed out that low temperature was one of the main factors that affects photosynthesis of vegetative tissue [34]. However, the effects of other stress factors on chlorophyll and other indicators are also different. The study results of Zhou indicated that photosynthetic indicators such as chlorophyll a, chlorophyll b, and carotenoid contents of Populus euphratica leaves under $\mathrm{NaCl}$ stress remained relatively stable [35], similar to the present results, in which there was no significant difference among groups A-F, D-F and A-D-F.

\section{Conclusions}

In this paper, alfalfa seedlings were used as experimental material, and the contents of malondialdehyde, soluble protein, soluble sugars, proline, and chlorophyll in the plants were measured to determine the responses of alfalfa to artificial acid precipitation, deicing salt and freezing-thawing. The accumulation of MDA content in alfalfa indicated that the cell membrane system was damaged. Moreover, the increasing content of soluble sugars and proline maintains osmotic balance, which could help plants to resist damage to adverse conditions. However, there was no regular change in chlorophyll content in plants under the combination of stress factors. In summary, the influence of stress from freezingthawing and deicing salt is highly substantial, while the combined stresses of acid precipitation with the two factors mentioned above has little effect on plants.

\section{Methods \\ Plant materials}

Approximately 1000 seeds of Dongmu-70 provided by the Life Sciences of Northeast Normal University of China were selected, soaked in $0.1 \%$ acidic $\mathrm{KMnO}_{4}$ solution for $2 \mathrm{~h}$, and then rinsed with distilled water. The seeds were then arranged onto trays and covered with two layers of filter paper, and $100 \mathrm{ml}$ of Hoagland nutrient solution was added. After the seeds germinated under dark conditions at $20^{\circ} \mathrm{C}$ for $24 \mathrm{~h}$ in an MGC450BP light incubator (Shanghai Yiheng Scientific Instruments Co., Ltd), full and similarly sized seedings were selected, placed on trays of $26 \times 18 \mathrm{~cm}$ (length $\times$ width; 23 lines $\times 40$ seeds per line) and then transferred to an MGC-450BP light incubator (Shanghai Yiheng Scientific Instruments Co., Ltd) under 12-h light (16,500 lx; $\left.25^{\circ} \mathrm{C}\right) / 12$-h dark $\left(0 \mathrm{~lx} ; 15^{\circ} \mathrm{C}\right)$ conditions for 1 week. Eight millilitres of nutrient solution was given every day $-40 \mathrm{ml}$ each morning and evening.

\section{Stress applications}

A deicing salt solution $(0.1 \mathrm{M}, 1000 \mathrm{ml})$ and an acid precipitation solution $(\mathrm{pH}=4.5$ (sulfuric acid:nitric acid $=3$ : 1), $1000 \mathrm{ml}$ ) were prepared. The seedlings were then evenly divided into eight groups: as A-D-F, A-F, D-F, AD, A, D, F and CK (Table 2). Seven millilitres of acid precipitation solution and $18 \mathrm{ml}$ of deicing salt solution were added to groups A-D-F and A-D, respectively, $7 \mathrm{ml}$ of acid precipitation solution and $18 \mathrm{ml}$ of distilled water were added to groups A and A-F, respectively, and $18 \mathrm{ml}$ of deicing salt and $7 \mathrm{ml}$ of distilled water were added to groups D and D-F, respectively. Twenty-five millilitres of distilled water was added to the $\mathrm{F}$ and $\mathrm{CK}$ groups. After the reagents were added, all the test group plants were placed in a light incubator under 12 -h light $(16,500 \mathrm{~lx}$; $\left.25^{\circ} \mathrm{C}\right) / 12$-h dark $\left(0 \mathrm{~lx} ; 15^{\circ} \mathrm{C}\right)$ conditions for $2 \mathrm{~d}$ and then were removed for the freeze-thaw treatment.

The A-D-F, D-F, A-F and F groups were subjected to freeze-thaw treatment, and the seedlings were put into a BPHJ-120A high-low temperature test chamber (Shanghai Yiheng Scientific Instruments Co., Ltd) to carry out a freeze-thaw cycle for a period of $14 \mathrm{~h}$, with a constant

Table 2 Experimental design of groups under acid precipitation (a), deicing salt (D) and freeze-thaw (F) stress

\begin{tabular}{lllllllll}
\hline & A-D-F & A-F & D-F & F & A-D & A & D & CK \\
\hline Acid precipitation & + & + & - & - & + & + & - & - \\
Deicing salt & + & - & + & - & + & - & + & - \\
Freeze-thaw & + & + & + & + & - & - & - & - \\
\hline
\end{tabular}

+ add stress, - no stress 
temperature curve including $10,5,0,-5,0,5$ and $10^{\circ} \mathrm{C}$ $(2 \sim 14 \mathrm{~h})$. The initial temperature of the BPHJ-120A high-low temperature growth chamber (Shanghai Yiheng Scientific Instruments Co., Ltd) was $15^{\circ} \mathrm{C}$, which was close to room temperature at night. The temperature dropped steadily to $-5{ }^{\circ} \mathrm{C}$ at a rate of $0.5^{\circ} \mathrm{C}$ every 12 min (approximately $0.04{ }^{\circ} \mathrm{C} / \mathrm{min}$ ), and then the temperature rose from -5 to $10^{\circ} \mathrm{C}$ at a rate of $0.5^{\circ} \mathrm{C}$ every $12 \mathrm{~min}$ (approximately $0.04{ }^{\circ} \mathrm{C} / \mathrm{min}$ ). Groups A-D, $\mathrm{D}, \mathrm{A}$, and CK were maintained in an MGC-450BP light incubator (Shanghai Yiheng Scientific Instruments Co., Ltd) with steady light conditions. At each temperature, 9-d-old samples were taken from each treatment group at random according to the amount required for the measurements, i.e., $0.5 \mathrm{~g}$ for measuring the malondialdehyde (MDA) and soluble sugar content, $0.1 \mathrm{~g}$ for the soluble protein content, and $0.5 \mathrm{~g}$ for the proline content.

\section{Biochemical characterization}

The MDA and soluble sugar contents were measured with the thiobarbituric acid (TBA) chromatometry method [36]. Leaf samples $(0.5 \mathrm{~g})$ were ground into a homogenate with $5 \mathrm{ml} \mathrm{10 \%} \mathrm{trichloroacetic} \mathrm{acid} \mathrm{(TCA)}$ solution. After centrifugation (TDL-40B, Anting Scientific Instrument Factory, Shanghai) at $4000 \mathrm{rpm}$ for 10 min, $2 \mathrm{ml}$ of the supernatant was transferred to tubes and mixed with $2 \mathrm{ml} 0.6 \%$ TBA solution. The mixture was immersed in boiling water for $15 \mathrm{~min}$ and then quickly cooled to room temperature. The absorbance at 450, 532 and $600 \mathrm{~nm}$ was then measured with a UV6100 UV-vis spectrophotometer (Metash Co., Ltd).

The content of soluble protein was determined by the Coomassie brilliant blue method [24]. Leaves $(0.1 \mathrm{~g})$ were ground into a homogenate with deionized water $(5 \mathrm{ml})$, which was subsequently centrifuged (TDL-40B, Anting Scientific Instrument Factory, Shanghai) for $10 \mathrm{~min}$ at 3000 $\mathrm{rpm}$. One millilitre of the supernatant was transferred to a test tube and diluted 5 times with deionized water $(4 \mathrm{ml})$. One millilitre of the diluted solution was mixed with $5 \mathrm{ml}$ of Coomassie brilliant blue G-250 (Shanghai Huishi Biochemical Reagent Co., Ltd). The absorbance was measured at $595 \mathrm{~nm}$ after $2 \mathrm{~min}$ with a UV-6100 UV-vis spectrophotometer (Metash Co. Ltd), and the protein content was determined via a standard curve [25].

The proline content was determined by the acid ninhydrin colourimetric method [37]. Afterward, $0.5 \mathrm{~g}$ of the sample was ground in $5 \mathrm{ml}$ of $3 \%$ sulfosalicylic acid solution into a homogenate. After extraction in a boiling water bath for $10 \mathrm{~min}$ and cooling to room temperature, the mixture was centrifuged (TDL-40B, Anting Scientific Instrument Factory, Shanghai) at $4000 \mathrm{rpm}$ for $10 \mathrm{~min}$. Two millilitres of the supernatant was removed and added to $2 \mathrm{ml}$ of icecold acetic acid and $3 \mathrm{ml}$ of colour reagent (2.5\% acidic ninhydrin). The mixture was subsequently immersed in a boiling water for $40 \mathrm{~min}$. Afterward, $5 \mathrm{ml}$ of toluene was added for extraction, and the absorbance was measured at a wavelength of $520 \mathrm{~nm}$.

The chlorophyll content in the leaves of plant seedlings was directly measured with a SPAD-502 Plus chlorophyll meter (Konica Minolta Holdings, Inc.); a single leaf was measured three times [38].

\section{Data processing}

Statistical analysis was performed with SPSS 16.0 statistical software (IBM SPSS Statistics, USA) using one-way analysis of variance (ANOVA), and multiple comparisons were performed on the basis of results of significance tests with the least significant difference (LSD) method. The significance level was 0.05 , and all the experimental data were plotted with Origin 8.0 software (OriginLab Corp.). The experiments were repeated three times, and all of the results are presented as the means \pm SEs.

\section{Supplementary information}

Supplementary information accompanies this paper at https://doi.org/10. 1186/s12870-020-02413-4.

\section{Additional file 1.}

Additional file 2.

Additional file 3.

Additional file 4.

Additional file 5 .

Abbreviations

MDA: Malondialdehyde; TBA: Thiobarbituric acid; TCA: Trichloroacetic acid

\section{Acknowledgements}

Not applicable.

\section{Authors' contributions}

GB, WT and QA designed the experiments; $Q A$ and $Y L$ performed most of the experiments; NZ performed part of the experiments; JT and SZ analyzed the data; and WT, NZ and JT wrote the manuscript. All authors agree with the manuscript contents and with its submission. All authors read and approved the final manuscript.

\section{Funding}

This work was supported by the National Natural Science Foundation of China under Grant No. 31772669. The funding bodies were not involved in the design of the study, collection, analysis, and interpretation of data, and in writing the manuscript.

\section{Availability of data and materials}

All data generated or analyzed during this study are included in this published article and its supplementary information files.

Ethics approval and consent to participate Not applicable.

Consent for publication

Not applicable.

Competing interests

The authors declare that they have no competing interests. 
Received: 16 December 2019 Accepted: 28 April 2020

Published online: 11 May 2020

\section{References}

1. Yang J, Zhou W, Liu J, Hu X. Dynamics of greenhouse gas formation in relation to freeze/thaw soil depth in a flooded peat marsh of Northeast China. Soil Biol Biochem. 2014;75:202-10.

2. Leon-Chan RG, Lopez-Meyer M, Osuna-Enciso T, Adriana Sanudo-Barajas J, Basilio Heredia J, Leon-Felix J. Low temperature and ultraviolet-B radiation affect chlorophyll content and induce the accumulation of UV-B-absorbing and antioxidant compounds in bell pepper (Capsicum annuum) plants. Environ Exp Bot. 2017;139:143-51.

3. Kaufmann $\mathrm{H}$, Blanke M. Changes in carbohydrate levels and relative water content (RWC) to distinguish dormancy phases in sweet cherry. J Plant Physiol. 2017;218:1-5.

4. Dai HL, Zhang KL, Xu XL, Yu HY. Evaluation on the Effects of Deicing Chemicals on Soil and Water Environment. In: Yang Z, Chen B, editors. 18th biennial isem conference on ecological modelling for global change and coupled human and natural system. Netherland: Procedia Environmental Sciences; 2012. p. 2122-30

5. Li F, Wu G, Hu S, Fan Z, Gao Q. Growth behavior and physiological characteristics of Chlorella vulgaris in the presence of deicing salt. In: Quan X, editor. 2013 International Symposium on Environmental Science And Technology. Netherland: Procedia Environmental Sciences; 2013. p. 20-5.

6. Cao J, Tie X, Dabberdt WF, Jie T, Zhao Z, An Z, et al. On the potential high acid deposition in northeastern China. J Geophys Res-Atmos. 2013;118(10): 4834-46.

7. Larssen T, Lydersen E, Tang DG, He Y, Gao JX, Liu HY, et al. Acid rain in China. Environ Sci Technol. 2006;40(2):418-25.

8. Wei WL, Cheng JM, Gao Y, Liu W. Effects of different site conditions on alfalfa field and path analysis in arid area of northern Weihe River basin. Bull Soil Water Conserv. 2010;30(05):6 (in Chinese).

9. Bertrand A, Bipfubusa M, Claessens A, Rocher S, Castonguay Y. Effect of photoperiod prior to cold acclimation on freezing tolerance and carbohydrate metabolism in alfalfa (Medicago sativa L.). Plant Sci. 2017;264: 122-8.

10. Wang RY, Ren Y, Yue W, Sun ZY, Dong KH, Yang GY. Effect of low temperature stress on the survival and physiological and biochemical indexes of alfalfa seedlings. Acta Laser Biology Sinica. 2006;4:7 (in Chinese).

11. Mao G, Xu X. Screening and physiological and biochemical analysis of Lycium barbarum mutant with salt tolerance. J Northwest Botanical Res. 2005;25(2):6 (in Chinese).

12. Gao Y, Qi XH, Yang JH, Zhang MF. The response mechanism of cold stress in higher plants. Northern Horticult. 2007;10:4 (in Chinese).

13. Liu ZQ, Zhang SC. Plant resistance physiology. Beijing: China Agriculture Press; 1994. (in Chinese).

14. Strand M, Öquist G. Effects of frost hardening, dehardening and freezing stress on in vivo chlorophyll fluorescence of seedlings of scots pine (Pinus sylvestris L.). Plant Cell Environ. 1988;11(4):231-8.

15. Zou Q. Experimental instruction of plant physiology. 1st ed. Beijing: China Agriculture Press; 2000. (in Chinese).

16. Georgieva K, Lichtenthaler HK. Photosynthetic activity and acclimation ability of pea plants to low and high temperature treatment as studied by means of chlorophyll fluorescence. J Plant Physiol. 1999;155(3):416-23.

17. Huff A. Peroxides-catalysed oxidation of chlorophyll by hydrogen peroxide. Phytochemistry. 1982;21(2):261-5.

18. Smart RE. Rapid estimates of relative water content. Plant Physiol. 1974; 53(2):258-60.

19. Marcum KB, Pessarakli M. Salinity tolerance of ryegrass turf cultivars. Hortscience. 2010;45(12):1882-4.

20. Zhang JY, Duan Z, Zhang DY, Zhang JQ, Di HY, Wu F, et al. Co-transforming bar and CSLEA enhanced tolerance to drought and salt stress in transgenic alfalfa (Medicago sativa L.). Biochem Biophys Res Commun. 2016;472(1):7582 (in Chinese).

21. Zhang EP, Zhang SH, Si LT, Pang JA, Ma DH. Effects of $\mathrm{NaCl}$ stress on the membrance lipid peroxidation in cotyledon of cucumber seedlings. J Shenyang Agric Univ. 2001;6:446-8 (in Chinese).

22. Lindlof A, Chawade A, Sikora P, Olsson O. Comparative transcriptomics of sijung and jumli marshi rice during early chilling stress imply multiple protective mechanisms. Plos One. 2015;10:5.
23. Fleck RA, Day JG, Clarke KJ, Benson EE. Elucidation of the metabolic and structural basis for the cryopreservation recalcitrance of Vaucheria sessilis. Cryo Lett. 1999;20(5):271-82.

24. Wu H, Zhang JS, Shi JY, Fan ZC, Aliyan R, Zhang P, et al. Physiological responses of cotton seedlings under low temperature stress. Acta Botan Boreali Occiden Sin. 2013;33(01):9 (in Chinese).

25. Hare PD, Cress WA, Van Staden J. Dissecting the roles of osmolyte accumulation during stress. Plant Cell Environ. 1998;21:6.

26. Li JH, Li JY, Dou ZJ. The effect of free froline treated under low temperature during reproductive period of rice varieties. J Cent China Norm Univ. 1985;3:4.

27. Ibrahim MEH, Zhu X, Zhou G, Ali AYA, Ahmad I, Farah GA. Nitrogen fertilizer alleviated negative impacts of nacl on some physiological parameters of wheat. Pak J Bot. 2018;50(6):2097-104.

28. Bertazzini M, Sacchi GA, Forlani G. A differential tolerance to mild salt stress conditions among six Italian rice genotypes does not rely on $\mathrm{Na}+$ exclusion from shoots. J Plant Physiol. 2018;226:145-53.

29. Moles TM, Mariotti L, Federico De Pedro L, Guglielminetti L, Picciarelli P, Scartazza A. Drought induced changes of leaf-to-root relationships in two tomato genotypes. Plant Physiol Biochem. 2018;128:24-31.

30. Karimzadeh G, Darvishzadeh R, Jalali-Javaran M, Dehghani H. Cold-induced accumulation of protein in the leaves of spring and winter barley cultivars. Acta Biol Hung. 2005:56(1-2):83-96.

31. Dhindsa SR, Plumb-Dhindsa LP, Reid MD. Leaf senescence and lipid peroxidation: effects of some phytohormones, and scavengers of free radicals and singlet oxygen. Physiol Plant. 1982;56(4):453-7.

32. Wang XK. Principles and techniques of plant physiological and biochemical experiments. 2nd ed. Beijing: Higher Education Press; 2006. (in Chinese).

33. Aroca R, Irigoyen JJ, Sanchez-Diaz M. Photosynthetic characteristics and protective mechanisms against oxidative stress during chilling and subsequent recovery in two maize varieties differing in chilling sensitivity. Plant Sci. 2001;161(4):719-26.

34. Xin Z, Browse J. Cold comfort farm: the acclimation of plants to freezing temperatures. Plant Cell Environ. 2000;23(9):893-902

35. Zhou T. Physiological responses of Populus euphratica and dynamic changes of miRNA expression under salt stress. Unpublished Doctoral dissertation. 2014. (in Chinese).

36. Bao G, Zhang M, Li Y, Chang Y, Tang W, Zhu S, et al. Physiological responses of alfalfa seedlings to freeze-thaw cycles and alkaline salt stress. Fresenius Environ Bull. 2019;28(5):4114-22.

37. Bao G, Ao Q, Li Q, Bao Y, Zheng Y, Feng X, et al. Physiological characteristics of medicago sativa $I$. in response to acid deposition and freeze-thaw stress. Water Air Soil Pollut. 2017;228:9.

38. Bian W, Bao G, Qian H, Song Z, Qi Z, Zhang M, et al. Physiological response characteristics in medicago sativa under freeze-thaw and deicing salt stress. Water Air Soil Pollut. 2018;229:6.

\section{Publisher's Note}

Springer Nature remains neutral with regard to jurisdictional claims in published maps and institutional affiliations.
Ready to submit your research? Choose BMC and benefit from:

- fast, convenient online submission

- thorough peer review by experienced researchers in your field

- rapid publication on acceptance

- support for research data, including large and complex data types

- gold Open Access which fosters wider collaboration and increased citations

- maximum visibility for your research: over $100 \mathrm{M}$ website views per year

At $\mathrm{BMC}$, research is always in progress.

Learn more biomedcentral.com/submission 